\title{
JURNAL Kefarmasian Indonesia
}

p-ISSN: 2085-675X e-ISSN: 2354-8770

\section{Kepatuhan Minum Obat pada Pasien Diabetes Melitus Tipe 2 di Beberapa Puskesmas Kabupaten Banyumas}

\author{
Medication Adherence in Patients with Type 2 Diabetes \\ in Several Health Centers of Banyumas District
}

\author{
Much Ilham Novalisa Aji Wibowo ${ }^{1,2}$, Febiana Melisa Fitri, Nanang Munif Yasin ${ }^{3 *}$, \\ Susi Ari Kristina ${ }^{4}$, Yayi Suryo Prabandari ${ }^{5}$
}

${ }^{1}$ Fakultas Farmasi, Universitas Muhammadiyah Purwokerto, Indonesia

${ }^{2}$ Program Doktor Ilmu Farmasi, Fakultas Farmasi, Universitas Gadjah Mada, Yogyakarta, Indonesia

${ }^{3}$ Departemen Farmakologi dan Farmasi Klinik, Fakultas Farmasi,

Universitas Gadjah Mada, Yogyakarta, Indonesia

${ }^{4}$ Departemen Farmasetik, Fakultas Farmasi, Universitas Gadjah Mada, Yogyakarta, Indonesia

${ }^{5}$ Departemen Kesehatan Masyarakat, Fakultas Kedokteran, Kesehatan Masyarakat, dan Keperawatan, Universitas Gadjah Mada, Yogyakarta, Indonesia

*E-mail: nanangy@yahoo.com

Kata kunci: Diabetes tipe 2; Kepatuhan; Puskesmas; MARS10; Prolanis

Keywords:

Type 2 diabetes;

Adherence;

Health center:

MARS-10,

Prolanis

Received:

11-08-2020

Revised:

11-02-2021

Accepted:

10-03-2021

Jurnal

Kefarmasian

Indonesia,

2021:11(2):98-108

DOI:

https://doi.org./10.22 435/jki.v11i2.3635

\section{Abstrak}

Diabetes Melitus (DM) dianggap sebagai "ibu” segala penyakit karena banyaknya komplikasi yang ditimbulkan. Mengetahui dan mengukur kepatuhan pengobatan dimungkinkan berpengaruh lebih besar pada pasien DM. Beberapa penelitian di Indonesia menggunakan skala kuesioner untuk mengukur kepatuhan namun tidak melakukan validasi terhadap populasi penelitiannya, sehingga masih ditemukan anomali analisis korelasi antara kepatuhan dan data kliniknya walaupun diukur pada negara dan skala yang sama. Penelitian ini mengukur tingkat kepatuhan minum obat pasien DM tipe 2, uji validitas skala pengukuran kepatuhan, dan analisis korelasinya terhadap outcome klinik pasien diabetes tipe 2 di empat Puskesmas wilayah Kab. Banyumas. Penelitian ini menggunakan desain cross-sectional pada pasien DM tipe 2 Prolanis, periode Januari sampai April 2020. Pengukuran kepatuhan dilakukan menggunakan MARS-10, metode terjemahan backward-forward lalu dilanjutkan validasi konten dan internal. Outcome klinik didasarkan pada pengukuran glukosa darah puasa. Hasil analisis index Gregory MARS10 menunjukkan validitas konten pada kategori tinggi $(\mathrm{IG} \geq 0,8)$. Validitas isi menunjukan hasil 9 pertanyaan bernilai $\mathrm{r}$ hitung $>\mathrm{r}$ tabel $(\mathrm{n}=30, \mathrm{r}$ tabel $=0,361)$. Analisis reliabilitas menunjukkan Cronbach's Alpha 0,747 > 0,6. Hasil pengukuran menunjukkan 80,3\% pasien patuh dan 19,3\% pasien tidak patuh. Analisis korelasi menunjukan tidak terdapat hubungan yang bermakna $(p>0,05)$ antara kepatuhan pasien dengan outcome klinik. Hal tersebut menunjukkan bahwa pasien DM tipe 2 di 4 Puskesmas Kab. Banyumas berkategori patuh minum obat tetapi tidak berkorelasi dengan outcome kliniknya. Hal ini dimungkinkan karena outcome klinik secara bersama-sama dipengaruhi beberapa faktor seperti: faktor umum, faktor individu, dan faktor lainnya yang tidak dapat diprediksi.

Abstract
Diabetes mellitus (DM) is considered as "the mother of all diseases" because it causes many complications. Knowing and measuring medication adherence may have a greater effect on DM patients. Several studies in Indonesia used a questionnaire scale to measure adherence, however they do not validate the study population, so it could still be found anomalous correlation analysis between adherence and clinical data even though it measured in the same country and scale. This study measure the adherence level of type 2 diabetes patients, evaluates the validity of the medication adherence scale, and analyze the correlation with the clinical outcome of type 2 diabetes patients in four health centers in Banyumas district. The study uses a cross-sectional design in Prolanis type 2 DM patients of January-April 2020. The adherence is measured by MARS-10, backward-forward translation method followed by content and internal validation. Clinical outcome is evaluated based on fasting blood glucose measurement. The results of the MARS-10 Gregory index analysis showed content validity in the high category $(I G \geq 0.8)$. The content validity showed the results of 9 questions with the value of $r$ count $>r$ table $(n=30, r$ table $=0.361)$. Reliability analysis showed Cronbach's Alpha 0.747> 0.6. The measurement showed $80.3 \%$ was adherent patients and $19.3 \%$ was non-adherent patients. Correlation analysis showed that there was no significant relationship ( $p>0.05)$ between patient adherence and clinical outcome. Those results showed that type 2 diabetes mellitus patients in 4 health centers were categorized as adherent but not correlated with the clinical outcome. This was enable due to the clinical outcome was simultaneously influenced by several factors: general factors, individual factors, and unpredictable factors. 


\section{PENDAHULUAN}

Diabetes Melitus (DM) dianggap sebagai "ibu segala penyakit" karena banyaknya komplikasi yang ditimbulkan. ${ }^{1}$ Salah satu usaha yang dapat dilakukan untuk mengurangi komplikasi tersebut adalah mengontrol glukosa pasien. ${ }^{2}$ Kontrol glukosa dapat dicapai melalui pengobatan farmakologis yang teratur. ${ }^{3}$ Keteraturan tersebut dapat dicapai dengan cara menjaga perilaku patuh terhadap pengobatan farmakologis agar mendapatkan manfaat klinik yang optimal. ${ }^{4}$ Ketidakpatuhan terhadap pengobatan dikaitkan dengan menurunnya outcome klinik jangka panjang, meningkatnya mortalitas, dan peningkatan biaya perawatan. ${ }^{5,6,7}$

Terdapat metode langsung dan tidak langsung untuk menilai kepatuhan pengobatan ${ }^{8}$. Metode tidak langsung lebih sering dilaporkan dalam penelitian pengukuran kepatuhan yaitu menggunakan skala kuesioner kepatuhan.,9 Walaupun sering digunakan akan tetapi terdapat kelemahan pada metode ini yaitu validitas dan reliabilitas yang bergantung pada kelengkapan dan keakuratan data pada populasi yang akan diukur, sehingga diperlukan pengukuran validitas pada setiap populasi yang berbeda dengan populasi uji skala ukurnya. ${ }^{10}$ Mengetahui dan mengukur kepatuhan pengobatan dimungkinkan berpengaruh lebih besar pada pasien DM daripada memberikan pengobatan yang lebih kompleks. ${ }^{11}$

Beberapa penelitian di Indonesia menggunakan skala kuesioner dalam penelitian pengukuran kepatuhan tetapi mayoritas tidak melakukan validasi terhadap populasi penelitiannya. ${ }^{12,13}$ Selain hal tersebut beberapa penelitian masih menemukan anomali analisis korelasi antara tingkat kepatuhan dan hasil data kliniknya walaupun diukur pada negara dan skala yang sama. ${ }^{14,15}$

Penelitian ini akan menguji validitas skala kepatuhan minum obat pada pasien DM tipe 2 di Puskesmas, mengukur tingkat kepatuhan pasien DM tipe 2, dan menganalisis korelasi kepatuhan minum obat terhadap outcome klinik pasien diabetes tipe 2 di empat Puskesmas wilayah Kab. Banyumas.

\section{METODE}

Penelitian ini menggunakan pendekatan observasional analitik dengan rancangan cross sectional. ${ }^{16}$ Penelitian dilakukan pada bulan Januari-April 2020. Kriteria inklusi yang ditetapkan adalah pasien DM tipe 2 yang tergabung dalam program pengelolaan penyakit kronis (Prolanis), pasien berusia $\geq 18-50$ tahun, menderita DM tipe $2 \geq 6$ bulan, pasien menggunakan antidiabetik oral, dan bersedia menjadi responden.

Teknik purposive sampling digunakan untuk memilih Puskesmas berdasarkan kasus DM tertinggi di wilayah kerja Dinas Kesehatan Banyumas ${ }^{1}$. Puskesmas tersebut adalah Puskesmas Wangon I, Puskesmas Sumbang I, Puskesmas Gumelar, dan Puskesmas Purwokerto Timur II. Responden penelitian berdasarkan teknik total sampling pada semua Puskesmas terpilih. Jumlah keseluruhan responden yang mengikuti penelitian ini adalah 96 pasien yang terbagi menjadi 2 bagian yaitu 66 pasien sebagai subjek uji kepatuhan dan 30 pasien sebagai subjek uji validasi instrumen di Puskesmas Gumelar.

Uji validitas skala yang dilakukan adalah validitas konten dan validitas internal. Validitas konten dianalisis menggunakan indeks kesepakatan Gregory Index ${ }^{17}$ dan validitas internal menggunakan analisis uji statistik Pearson Product Moment. ${ }^{18}$ Uji reliabilitas instrumen menggunakan uji statistik Alpha Cronbach's. ${ }^{18}$ Penilaian kesepakatan ahli menggunakan skala Likert (Skor1: Tidak Valid, Skor 2= kurang valid, Skor 3= cukup valid, skor $4=$ valid, skor $5=$ sangat valid). Klasifikasi indeks kesepakatan para ahli yaitu $\leq 0,4$ bermakna indeks kesepakatan rendah, 0,4-0,8 bermakna indeks kesepakatan sedang dan jika $\geq 0,8$ bermakna indeks kesepakatan tinggi. ${ }^{17}$ Hubungan antar variabel diuji secara statistik menggunakan uji Spearman rho untuk mengetahui hubungan antara 
kepatuhan dan outcome klinik pasien DM tipe $2 .^{18}$

Tingkat kepatuhan minum obat diukur menggunakan instrumen kepatuhan Medication Adherence Rating Scale-10 (MARS-10). Instrumen ini berisi 10 pertanyaan yang memiliki validitas dan reliabilitas yang baik pada pasien dengan penyakit kronik. $^{19} \quad$ Responden dikategorikan tidak patuh jika hasil pengukuran menunjukkan skor 1-5 dan patuh jika total skor 6-10. ${ }^{19}$ Instrumen MARS-10 diterjemahkan dalam bahasa Indonesia menggunakan metode forwardbackward translation. ${ }^{20}$ Translasi dilakukan oleh 2 lembaga bahasa inggris berkualifikasi nasional yaitu Language Development Center Universitas Muhammadiyah Purwokerto (LDC UMP) dan English Language Training International (ELTI) Purwokerto.

Data sosio demografi pasien dikumpulkan menggunakan lembar pengumpul data. Data outcome klinik diperoleh dari data pengukuran gula darah puasa (GDP) yang dilakukan oleh Puskesmas pada setiap kegiatan Prolanis. Outcome klinik yang diperoleh dibagi menjadi 2 kategori yaitu: tercapai (nilai GDP $\leq 125 \mathrm{mg} / \mathrm{dl}$ ) dan tidak tercapai (nilai GDP pasien $\geq 126 \mathrm{mg} / \mathrm{dl}$ ).

Pengumpulan data dilakukan secara langsung saat kegiatan Prolanis di Puskesmas menggunakan metode paper and pen/pencil interviewing (PAPI). ${ }^{21}$ Pasien yang sesuai kriteria inklusi akan ditanya kesediaannya untuk mengikuti penelitian dan mengisi lembar informed consent. Peneliti menyerahkan lembar pengumpul data sosio demografi dan instrumen MARS-10 untuk diisi kemudian pasien diukur outcome kliniknya oleh petugas Puskesmas.

Penelitian ini telah mendapatkan izin etik Fakultas Kedokteran Universitas Jendral Soedirman ref: 0006/KEPK/I/2020 dengan hasil telaah etik exempted dan izin dinas kesehatan Kab. Banyumas No.070.1/718/XI/2019.

\section{HASIL DAN PEMBAHASAN}

\section{Karakteristik responden}

Jumlah keseluruhan responden adalah 96 sampel yang tersebar di 4 Puskesmas. 66 responden pengukuran kepatuhan dan 30 responden uji validasi. Proses seleksi inklusi dan eksklusi keseluruhan responden yang mengikuti penelitian ini dapat dilihat pada Gambar 1.

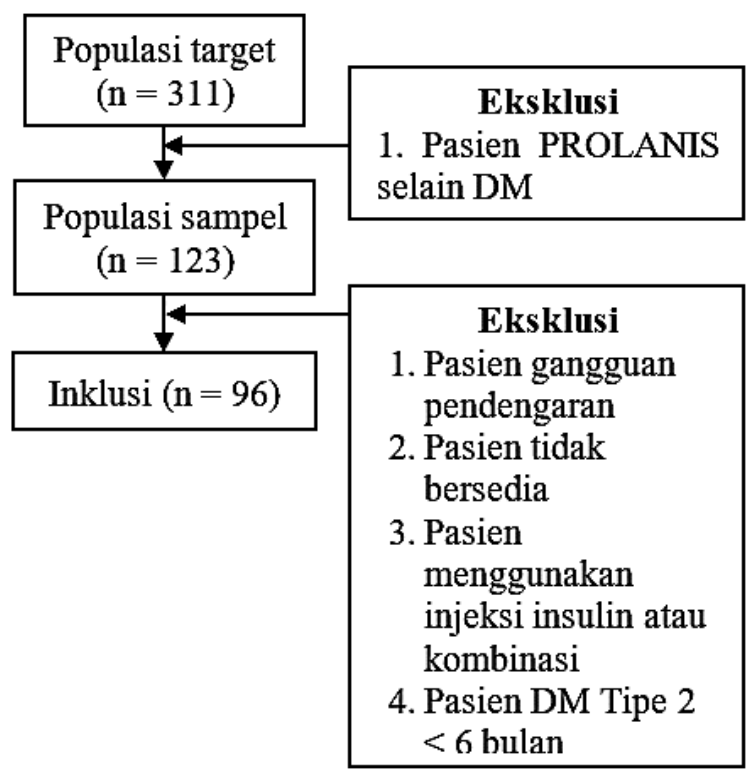

\section{Gambar 1. Distribusi sampel penelitian di Puskesmas Kab. Banyumas}

Data populasi sampel dapat menggambarkan aspek sosio demografi pasien DM Tipe 2 di 4 Puskesmas Kab. Banyumas pada rentang periode Januari April 2020. Data tersebut disajikan pada Tabel 1. Mayoritas pasien DM tipe 2 di empat Puskesmas adalah Perempuan. Beberapa penelitian menemukan fakta yang sama terkait dengan jenis kelamin pasien DM tipe 2.22,23

Pasien DM tipe 2 pada penelitian ini terkonsentrasi pada rentang umur 51-71 tahun dan telah mengidap DM selama $>5$ tahun (Tabel 1). Usia tersebut dalam kategori geriatri yang cenderung mengalami penurunan sensitivitas insulin dan fungsi 
Tabel 1. Karakteristik pasien diabetes tipe 2 di Puskesmas wilayah Banyumas

\begin{tabular}{|c|c|c|}
\hline Karakteristik & $\sum_{(96)}$ subyek & $\mathbf{N}(\%)$ \\
\hline \multicolumn{3}{|l|}{ Jenis kelamin } \\
\hline Laki-laki & 26 & 16,7 \\
\hline Perempuan & 70 & 83,3 \\
\hline \multicolumn{3}{|l|}{ Umur } \\
\hline $18-50$ tahun & 16 & 16.7 \\
\hline $51-60$ tahun & 33 & 34.4 \\
\hline $61-70$ tahun & 31 & 32.3 \\
\hline $71-80$ tahun & 16 & 16.7 \\
\hline \multicolumn{3}{|l|}{ IMT* } \\
\hline Kurus & 3 & 9.4 \\
\hline Normal & 26 & 33.3 \\
\hline BB lebih & 12 & 18.8 \\
\hline Obesitas I & 22 & 29.2 \\
\hline Obesitas II & 3 & 9.4 \\
\hline \multicolumn{3}{|l|}{ Pekerjaan } \\
\hline IRT** & 48 & 50.0 \\
\hline Pedagang & 12 & 12.5 \\
\hline Pensiunan/tidak bekerja & 11 & 11.5 \\
\hline Wiraswasta & 9 & 9.4 \\
\hline Buruh & 9 & 9.4 \\
\hline Petani & 7 & 7.3 \\
\hline \multicolumn{3}{|l|}{ Tingkat pendidikan } \\
\hline Tidak sekolah & 14 & 14.6 \\
\hline SD & 35 & 36.5 \\
\hline SMP & 21 & 21.9 \\
\hline SMA & 16 & 16.7 \\
\hline $\mathrm{S} 1$ & 10 & 10.4 \\
\hline \multicolumn{3}{|l|}{ Durasi penyakit } \\
\hline$<5$ tahun & 42 & 43.8 \\
\hline$>5$ tahun & 54 & 56.3 \\
\hline \multicolumn{3}{|l|}{ Tinggal bersama keluarga } \\
\hline $\mathrm{Ya}$ & 77 & 80.2 \\
\hline Tidak & 19 & 19.8 \\
\hline \multicolumn{3}{|l|}{ Status merokok } \\
\hline $\mathrm{Ya}$ & 18 & 18.7 \\
\hline Tidak & 78 & 81.2 \\
\hline \multicolumn{3}{|l|}{ Jenis terapi obat } \\
\hline Tunggal (1 obat) & 34 & 35.4 \\
\hline Kombinasi (>1 obat) & 62 & 64.6 \\
\hline \multicolumn{3}{|l|}{ Frekuensi minum obat } \\
\hline 1x sehari & 20 & 20.8 \\
\hline $2 \mathrm{x}$ sehari & 51 & 53.1 \\
\hline$\geq 3 \times$ sehari & 25 & 26.0 \\
\hline \multicolumn{3}{|l|}{ Nama obat } \\
\hline Glimepiride & 12 & 12.5 \\
\hline Metformin & 20 & 20.8 \\
\hline Glimepiride + metformin & 47 & 49.0 \\
\hline $\begin{array}{l}\text { Glimepiride }+ \text { metformin }+ \\
\text { acarbose }\end{array}$ & 10 & 10.4 \\
\hline Metformin + acarbose & 7 & 7.3 \\
\hline $\begin{array}{l}\text { Sumber: data primer, } 2020 \\
\text { *Indeks massa tubuh } \\
\text { **Ibu rumah tangga }\end{array}$ & & \\
\hline
\end{tabular}

tubuh untuk melakukan metabolisme glukosa yang dihasilkan dari makanan, sehingga menjadi faktor predisposisi terhadap munculnya penyakit DM pada usia tersebut. ${ }^{24,25}$ Data penelitian menunjukan mayoritas pasien berstatus sebagai ibu rumah tangga dengan pendidikan yang diselesaikan masih tergolong rendah (Tabel 1).

Responden telah mengidap DM tipe 2 selama lebih dari 5 tahun dan tinggal bersama keluarganya. Keluarga dapat memberikan dukungan dalam menjalankan terapi dengan cara memberikan motivasi. ${ }^{26}$ Dalam penelitian ini mayoritas pasien mendapatkan kombinasi lebih dari 1 obat dengan frekuensi lebih dari $1 \mathrm{x}$ sehari. Kompleksitas regimen yang diresepkan oleh dokter dapat diminimalisir dengan cara dukungan dan motivasi dari keluarga. $^{27}$

\section{Validasi instrumen MARS-10}

Langkah awal uji validasi adalah melakukan translasi instrumen original MARS-10 yang berbahasa Inggris menggunakan metode forward-backward translation dari 2 lembaga bahasa inggris Language Development Center Universitas Muhammadiyah Purwokerto (LDC UMP) \& English Language Training International (ELTI). ${ }^{20}$ Hasil translasi tersebut diuji melalui uji validitas konten/isi dengan beberapa ahli yang dipilih berdasarkan keahlian khusus pada suatu topik yaitu tingkat akademik, pengalaman dalam pekerjaan, dan penelitian yang dilakukan. ${ }^{28}$ Validasi konten/isi mengikutsertakan para ahli yang menangani pasien secara langsung. Ahli tersebut adalah dokter dan apoteker yang melakukan program PROLANIS di 3 Puskesmas yaitu Puskesmas Wangon I, Sumbang I, dan Purwokerto Timur II sehingga jumlah keseluruhan ahli adalah 6 orang ahli. Selanjutnya para ahli mengoreksi semua item pertanyaan melalui index Gregory. ${ }^{17}$ Hasil index kesepakatan tersebut disajikan pada Tabel 2. 
Tabel 2. Validitas konten oleh Ahli

\begin{tabular}{lc}
\hline \multicolumn{1}{c}{ Puskesmas } & Index Gregory \\
\hline Wangon I & 1,0 \\
Sumbang I & 0,6 \\
Purwokerto Timur II & 0,9 \\
\hline Rata-rata $\bar{X}$ & 0.83 \\
\hline
\end{tabular}

Sumber: data primer, 2020

Hasil analisis Gregory Index menunjukan instrumen MARS-10 versi bahasa indonesia memiliki rerata validitas konten/isi pada kategori tinggi (indeks Gregory $\geq 0,8$ ) pada pasien DM tipe $2 .^{17}$ Validitas konten/isi suatu instrumen tidak mempunyai besaran tertentu yang dihitung secara statistika, tetapi dipahami bahwa instrumen tersebut telah valid berdasarkan telaah para ahli. Penilaian validitas konten berdasar analisis logika bahwa terjemahan instrumen MARS-10 telah representatif untuk mengukur kepatuhan minum obat pasien DM tipe 2 di Puskesmas Kab. Banyumas.

Uji validitas selanjutnya adalah validitas internal atau validitas butir kepada 30 responden di Puskesmas Gumelar sesuai kriteria inklusi. ${ }^{18}$ Pengujian ini diperlukan agar alat ukur yang digunakan secara konsep dapat digunakan pada pasien DM tipe 2 di Indonesia. ${ }^{17} \quad$ Validitas internal menghasilkan analisis seberapa jauh hasil pengukuran butir tersebut konsisten dengan hasil ukur instrumen secara keseluruhan. ${ }^{17}$ Pengujian validitas internal instrumen menggunakan uji statistik Pearson product moment Hasil analisis tersebut disajikan pada Tabel 3.

\section{Tabel 3. Uji Validitas Instrumen MARS-10}

\begin{tabular}{cc}
\hline No item & Nilai koefisien korelasi $(\boldsymbol{r})$ \\
\hline 1 & 0,499 \\
2 & 0,554 \\
3 & 0,552 \\
4 & 0,570 \\
5 & 0,665 \\
6 & 0,684 \\
7 & 0,684 \\
8 & 0,668 \\
9 & 0,355 \\
10 & 0,668 \\
\hline
\end{tabular}

Sumber: data primer, 2020
Nilai $r$ hitung $>r$ tabel $(\mathrm{n}=30, r$ tabel $=$ 0,361 ) lebih besar dari $r$ tabel, instrumen tersebut dinilai reliabel digunakan pada pasien DM tipe 2 di Puskesmas wilayah Kab. Banyumas. Item 9 diperoleh nilai $r$ hitung $=0,355$ lebih kecil dari $r$ tabel tetapi pada hasil penilaian validitas isi para ahli menyepakati bahwa nomor 9 dinilai valid dengan kategori indeks Gregory $\geq$ 0,8 sehingga pertanyaan instrumen no. 9 dapat digunakan. ${ }^{17}$

validitas internal/butir tercermin pada besaran koefisien korelasi antara skor butir dan skor total instrumen. ${ }^{17}$ Jika koefisien korelasi antara skor butir dengan skor total instrumen positif dan signifikan, maka butir tersebut dapat dianggap valid berdasarkan ukuran validitas internal. ${ }^{17}$ Kemudian dilanjutkan uji reliabilitas menggunakan Cronbach Alpha Coefficient. Hasil uji reliabilitas dikatakan reliable apabila nilai Cronbach Alpha Coefficient adalah >0,6. ${ }^{18,29}$ Hasil uji reliabilitas instrumen MARS-10 dapat dilihat pada Tabel 4.

\section{Tabel 4. Hasil Uji Reliabilitas Instrumen MARS-10}

\begin{tabular}{cc}
\hline Cronbach's Alpha & N of Items \\
\hline 0,747 & 10 \\
\hline Sumber: data primer, 2020
\end{tabular}

Hasil tersebut menyatakan instrumen MARS-10 reliable untuk mengukur tingkat kepatuhan pasien dalam minum obat pasien DM tipe 2 di Puskesmas Kab. Banyumas. Kedua pengujian tersebut mengindikasi bahwa instrumen MARS-10 versi bahasa Indonesia valid dan reliable untuk mengukur tingkat kepatuhan minum obat pasien DM tipe 2 di Puskesmas. Uji validitas item pertanyaan pada instrumen MARS-10 memiliki ketepatan untuk mengukur apa yang hendak diukur dan konsisten bila digunakan berkali-kali pada waktu dan tempat yang relatif sama akan menghasilkan data yang relatif sama. ${ }^{17,18}$ Penelitian yang dilakukan di Jerman bahwa instrumen MARS-10 dapat digunakan untuk mengukur kepatuhan pasien dalam meminum obat dikarenakan 
MARS-10 berfungsi sebagai instrumen yang mendeteksi perilaku ketidakpatuhan pasien meminum obat dan mudah digunakan ${ }^{30}$. Validasi terjemahan instrumen MARS-10 ini akan memastikan ketersediaan instrumen untuk para peneliti dan professional kesehatan di negara lain untuk diterjemahkan dalam bahasa asli dan memvalidasinya pada populasi lain. Hasil validasi memperlihatkan bahwa instrumen MARS-10 dalam versi bahasa Indonesia memiliki ketepatan untuk mengukur kepatuhan pasien DM tipe 2 dan konsisten bila digunakan berkali-kali akan memperoleh hasil yang relatif sama.

\section{Kepatuhan pasien DM tipe 2 di Puskesmas}

Pengukuran kepatuhan dilakukan kepada 66 responden di 3 Puskesmas yaitu, Puskesmas Wangon I, Sumbang I dan Purwokerto Timur II. Nilai akhir diperoleh dengan cara menjumlahkan skor berdasarkan jawaban responden pada instrumen. Hasil penilaian kepatuhan pasien dalam minum obat dapat dilihat pada Tabel 5.

Tabel 5. Kepatuhan Pasien Diabetes Melitus Tipe 2 berdasarkan MARS-10

\begin{tabular}{cccc}
\hline Skor & Kategori & Frek (f) & $\begin{array}{c}\text { Persentase } \\
(\%)(\mathbf{n = 6 6})\end{array}$ \\
\hline $1-5$ & Tidak patuh & 13 & $19,3 \%$ \\
$6-10$ & Patuh & 53 & $80,3 \%$ \\
\hline
\end{tabular}

Sumber: Data Primer, 2020

Pada Tabel 5 menunjukan bahwa kepatuhan pasien DM tipe 2 di Puskesmas Kab. Banyumas berdasarkan skor penilaian instrumen MARS-10 diperoleh mayoritas patuh mengkonsumsi obat. Tingkat kepatuhan yang diperoleh penelitian ini lebih tinggi dibandingkan dengan tingkat kepatuhan yang ditemukan di beberapa negara seperti India $76,3 \%{ }^{31}$, Ethiopia $54,8 \%^{32}$, Malaysia $47 \%{ }^{33}$, Jepang $49,8 \%{ }^{34}$. Penelitian lain di Indonesia yang menggunakan skala ukur yang sama menemukan hasil tingkat kepatuhan berkategori rendah. ${ }^{12,13}$ Perbedaan hasil ini dimungkinkan karena sampel penelitian adalah peserta Prolanis yang relatif rutin melakukan serangkaian kegiatan secara rutin setiap bulan serta menerima obat anti diabetik secara rutin sehingga mengurangi kemungkinan faktor ketidakpatuhan pasien dalam mengkonsumsi obat. ${ }^{31}$ Evaluasi tingkat kepatuhan pasien yang sudah diketahui dapat bermanfaat bagi apoteker dan dokter dalam menentukan intervensi dan meningkatkan kepatuhan pasien. ${ }^{35}$

\section{Outcome klinik pasien DM tipe 2 di Puskesmas}

Outcome klinik diukur berdasarkan kadar gula darah puasa (GDP) pada saat pasien melakukan kegiatan PROLANIS. Data outcome klinik responden dapat dilihat pada Tabel 6 .

\section{Tabel 6. Outcome Klinik Pasien DM tipe 2}

\begin{tabular}{lcc}
\hline Kategori & $\begin{array}{c}\text { Responden } \\
(\mathbf{N = 6 6 )}\end{array}$ & $\begin{array}{c}\text { Persentase } \\
(\mathbf{\%})\end{array}$ \\
\hline Tercapai & 28 & 42,2 \\
Tidak tercapai & 38 & 57,6 \\
Total & 66 & 100 \\
\hline
\end{tabular}

Sumber: data primer, 2020

Outcome klinik pasien DM tipe 2 di 3 Puskesmas tempat penelitian tidak tercapai berdasarkan standar outcome klinik pasien DM tipe 2 sesuai kriteria inklusi penelitian $^{24}$. Secara tidak langsung hal ini menjadi indikator bahwa keberhasilan terapi pasien DM tipe 2 di Puskesmas Kab. Banyumas belum tercapai. Hasil ini sejalan dengan penelitian lainnya yang juga menyatakan bahwa terapi yang dijalankan pasien tidak berhasil dikarenakan kadar gula darah pasien berada pada rentang yang melebihi standar. ${ }^{36}$ Beberapa faktor dapat mempengaruhi hasil pengukuran outcome klinik ini yaitu ketepatan peresepan obat anti diabetik oral dari pemilihan jenis obat serta frekuensi minum obat maupun dosis yang sesuai, gaya hidup, diet khusus, dan kepatuhan pasien dalam meminum obat serta konseling apoteker kepada pasien. ${ }^{37,38}$ 


\section{Hubungan antara kepatuhan pasien dengan outcome klinik}

Pengujian selanjutnya adalah mengetahui hubungan antara kepatuhan pasien dengan hasil outcome kliniknya. Analisis hubungan tersebut dapat dilihat pada Tabel 7.

\section{Tabel 7. Hubungan kepatuhan pasien dengan outcome klinik}

\begin{tabular}{ccccc}
\hline $\begin{array}{c}\text { Kate- } \\
\text { gori }\end{array}$ & N (\%) & $\begin{array}{c}\text { Ter- } \\
\text { capai }\end{array}$ & $\begin{array}{c}\text { Tidak } \\
\text { tercapai }\end{array}$ & $\begin{array}{c}\boldsymbol{P} \\
\text { Spearm } \\
\text { an }\end{array}$ \\
\hline Patuh & $53(80,3)$ & 24 & 29 & \\
Tidak & $13(19,7)$ & 4 & 9 & 0,350 \\
patuh & $66(100 \%)$ & 28 & 38 & \\
Total & 62 & &
\end{tabular}

Sumber data: data primer, 2020

Hasil analisis menemukan bahwa tidak terdapat hubungan yang bermakna sig.(2tailed) $(\mathrm{p}>0,05)$ antara kepatuhan pasien dengan outcome klinik. Data ini diperkuat dengan hasil correlation coefficient analisis spearman sebesar 0,117 yang bermakna bahwa tingkat keeratan korelasi antara variabel kepatuhan dan outcome klinik bernilai rendah pada tingkat kepercayaan $95 \%$. Terdapat dua penelitian lain di Indonesia yang menemukan hal yang sama, yaitu tidak ditemukan korelasi antara kepatuhan dan outcome kliniknya. ${ }^{37,39}$ Meskipun penelitian lain ada yang menyatakan kepatuhan berkorelasi terhadap outcome klinik. ${ }^{12}$ Anomali ini juga ditemukan pada beberapa penelitian serupa di negara lain yang menggunakan skala ukur berbasis kuesioner. ${ }^{40,41}$ Selain kepatuhan minum obat, out come klinik secara bersama sama dipengaruhi beberapa faktor umum (pola makan, kehamilan, obat dan vitamin, status merokok dan alkohol), faktor individu (dawn phenomenon, stres, dan aktivitas fisik), dan faktor yang tidak dapat diprediksi (stres dan penyakit penyerta). ${ }^{42}$ Salah satu keterbatasan penelitian dalam ini adalah faktor-faktor tersebut tidak dikontrol.

Penelitian ini menemukan fakta bahwa kategori penilaian kepatuhan minum obat pasien DM tipe 2 berdasarkan skala
MARS-10 mayoritas pada kategori patuh $80,3 \%$ (Tabel 5), tetapi tidak diikuti dengan hasil outcome klinik yang didapatkan yaitu tidak tercapai $57,6 \%$ (Tabel 6). Penelitian ini mendukung hasil penelitian lain pada populasi penyakit DM dan menggunakan basis skala kepatuhan yang sama. ${ }^{37,39,41}$ Secara teori jika pasien patuh minum obat maka outcome yang didapatkan seharusnya berkategori baik atau normal. ${ }^{4}$ Perbedaan hasil ini mungkin disebabkan oleh berbagai faktor, yaitu faktor internal atau faktor eksternal pada pasien DM tipe 2 di Puskesmas. ${ }^{43}$

Faktor internal seperti perilaku kepatuhan muncul dari karakteristik pasien yang dapat mempengaruhi kepatuhan minum obat khususnya pada pasien geriatri. $^{44}$ Salah satunya adalah pengukuran outcome berupa GDP pada penelitian ini yang bisa terjadi kesalahan preparasi ukur seperti pasien tidak benarbenar melakukan puasa selama 12 jam sebelum pengukuran, walaupun telah diberitahu oleh petugas Puskesmas. ${ }^{24}$

Kebiasaan sarapan masyarakat Indonesia tergolong baik, namun dengan porsi karbohidrat yang lebih besar dari nutrisi lainnya dan minum minuman dengan kadar gula yang tinggi. ${ }^{45} \mathrm{Hal}$ ini menyebabkan produksi glukosa telah meningkat saat dilakukan pengukuran kadar glukosa darah di Puskesmas. Kebiasaan ini dapat menimbulkan bias pengukuran kadar glukosa pasien DM. Pengukuran outcome klinik kadar glukosa darah telah menjadi standar pelayanan kesehatan di Puskesmas bagi pasien DM tipe 2 yang tergabung dalam Prolanis karena harga yang relatif lebih rendah dari pengukuran outcome pasien DM tipe 2 yang lain seperti pengukuran konsentrasi HbA1c.

Pengukuran outcome klinik selain pengukuran GDP adalah pengukuran nilai HbA1c. ${ }^{46}$ Kadar glukosa darah (sewaktu, puasa, atau setelah makan) dapat berubah secara cepat berdasarkan kegiatan dan pola makanan pasien DM, sehingga relatif kurang akurat untuk mengukur outcome klinik pengobatan pasien DM tipe $2 .^{47,48}$ 
Berbeda dengan HbA1c yang merupakan jenis protein mayoritas dan memiliki kandungan zat besi dalam sel darah merah. ${ }^{47}$ Saat $\mathrm{Hb}$ bereaksi dengan suatu zat berkadar glukosa tinggi rantai beta molekul hemoglobin akan mengikat gugus glukosa secara irreversible. Reaksi glikosilasi protein ini yang membentuk hemoglobin glioksilat. ${ }^{48}$ Kadar HbA1c berubah secara perlahan, sehingga bisa digunakan untuk menilai kepatuhan minum obat pasien DM dan sebagai kontrol gula darah utama. ${ }^{41,46,49}$

Beberapa penelitian mengungkapkan terdapat hubungan yang konsisten antara kepatuhan minum obat dengan kadar HbA1c. ${ }^{46,49}$ Pengukuran HbA1c memiliki akurasi dan presisi lebih baik dibandingkan dengan pemeriksaan kadar glukosa. ${ }^{48}$ Namun, faktor harga yang relatif tinggi untuk pemeriksaan dan pengukuran $\mathrm{HbA} 1 \mathrm{c}$ menjadi pertimbangan dalam penelitian pengukuran kepatuhan minum obat termasuk dalam penelitian ini.

Faktor eksternal dimungkinkan karena instrumen MARS-10 tidak sesuai digunakan untuk pasien DM tipe 2, walaupun hasil uji validitas menyatakan MARS-10 valid dan reliabel pada populasi penelitian (Tabel 3 dan 4). Seperti halnya instrumen kepatuhan MMAS-8 yang ditemukan beberapa kelemahan jika digunakan pada pasien selain populasi pasien hipertensi. ${ }^{41,50,51}$ Beberapa penelitian juga menyatakan kelemahan penggunaan instrumen MMAS-8 jika digunakan pada populasi pasien DM tipe 2. ${ }^{41,50,51}$ Menurut ketiga penelitian tersebut terdapat kemungkinan penaksiran penilaian yang terlalu tinggi oleh pasien DM tipe 2 sehingga menyebabkan ketidakakuratan pengukuran. Instrumen MMAS-8 dianggap kurang spesifik karena tujuan awal pembuatan alat ukur tersebut adalah pada populasi pasien hipertensi bukan untuk mengukur kepatuhan minum obat pada penyakit yang berkaitan dengan gangguan psikiatri. ${ }^{52-55}$ Kelemahan skala pengukuran kepatuhan MARS-10 pada pasien DM tipe 2 dimungkinkan juga sama seperti MMAS-8 pada pasien psikiatri, sehingga menimbulkan penaksiran penilaian yang terlalu tinggi oleh pasien DM tipe 2 walaupun pengukuran validitas dan reliabilitas mendapatkan skor nilai yang dianggap memenuhi kriteria yang baik.

Peneliti menyadari terdapat beberapa keterbatasan yang teridentifikasi dalam penelitian ini, yaitu penggunaan desain cross-sectional yang tidak bisa menunjukkan arah hubungan kausal antara variabel kepatuhan dan variabel outcome klinik. Kepatuhan diukur menggunakan skala yang tidak spesifik pada pasien DM tipe 2 sehingga kemungkinan terjadi ketidakakuratan respon pasien. Penanda biologis diabetes sebaiknya menggunakan konsentrasi HbA1c sebagai standar utama pengukuran kadar gula dalam darah. Penelitian ini fokus pada tujuan penelitian sehingga tidak menganalisis pengaruh faktor sosio demografi terhadap kepatuhan. Penelitian selanjutnya disarankan menggunakan desain penelitian yang komprehensif dengan skala ukur kepatuhan spesifik dan sampel yang lebih besar serta analisis korelasi faktor sosio demografi terhadap kepatuhan.

\section{KESIMPULAN}

Hasil uji validitas MARS-10 yang baik pada pasien DM tipe 2 di Puskesmas wilayah Kab. Banyumas harus digunakan secara hati-hati karena skala tersebut tidak spesifik untuk mengukur kepatuhan pasien DM tipe 2. Hasil pengukuran kepatuhan yang berkategori patuh ternyata tidak berkorelasi terhadap outcome klinik konsentrasi glukosa darah responden yang tidak mencapai standar normalnya.

\section{SARAN}

Disarankan menggunakan parameter konsentrasi HbA1c sebagai outcome klinik pengobatan pasien DM tipe 2.

\section{UCAPAN TERIMA KASIH}

Terimakasih kepada pihak dinas kesehatan Kab. Banyumas yang telah mengizinkan penelitian ini dilaksanakan 
dan para tenaga kesehatan yang telah mendukung penelitian ini.

\section{DAFTAR RUJUKAN}

1. Badan Litbang Kesehatan. Hasil utama riset kesehatan dasar [Internet]. Jakarta: Badan Litbang Kesehatan; 2018 [disitasi 15 Oktober 2019]. Diperoleh dari: https://www.litbang.kemkes.go.id/hasilutama-riskesdas-2018/

2. Rodríguez-Gutiérrez R, Montori VM. Glycemic control for patients with type 2 diabetes mellitus: our evolving faith in the face of evidence. Circulation Cardiovascular Quality Outcomes. 2016 Sep;9(5):504-12.

3. Verhulst MJL, Loos BG, Gerdes VEA, Teeuw WJ. Evaluating all potential oral complications of diabetes mellitus. Front Endocrinol. 2019 Feb 18;10(56).

4. Chaudhury A, Duvoor C, Dendi VSR, Kraleti S, Chada A, Ravilla R, et al. Clinical review of antidiabetic drugs: implications for type 2 diabetes mellitus management. Front Endocrinol. 2017;8(6).

5. Xu W-H, Han B-S, Ma L-L, Guo W-J, Zhang X-J, Feng B. Relationship between statin adherence and long-term clinical consequences in patients with cardiovascular disease: a systematic review and meta-analysis. International Journal of Clinical and Experimental Medicine. 2016;9(6):9195-202.

6. Cutler RL, Fernandez-Llimos F, Frommer M, Benrimoj C, Garcia-Cardenas V. Economic impact of medication nonadherence by disease groups: a systematic review. The BMJ. 2018 Jan;8(1):e016982.

7. Andayani TM, Ibrahim MIM, Asdie AH. Assessing the impact of complications on the direct medical costs of type 2 diabetes mellitus outpatients. International Journal of Current Pharmaceutical Research. 2010;2(2):32-5.

8. Capoccia K, Odegard PS, Letassy N. Medication adherence with diabetes medication: a systematic review of the literature. The Diabetes Educator. 2016;42(1):34-71.

9. Kristina SA, Wulandari GP. Medication adherence using self-report measures among chronic disease patients: a review.
International Journal of Pharmaceutical Research. 2020 Jan;12(1):426-35.

10. Chung WW, Chua SS, Lai PSM, Morisky DE. The Malaysian medication adherence scale (MALMAS): concurrent validity using a clinical measure among people with type 2 diabetes in Malaysia. PLoS ONE. 2015 April 24;10(4):1-11.

11. Brown MT, Bussell J, Dutta S, Davis K, Strong S, Mathew S. Medication adherence: truth and consequences. The American Journal of Medical Sciences. 2016 Apr;351(4):387-99.

12. Katadi S, Andayani TM, Endarti D. Hubungan kepatuhan pengobatan dengan outcome klinik dan kualitas hidup pasien diabetes melitus tipe 2. Jurnal Manajemen dan Pelayanan Farmasi. 2019;9(1):19-26.

13. Akrom A, Sari OM, Urbayatun S, Saputri Z. Analisis determinan faktor-faktor yang berhubungan dengan kepatuhan minum obat pasien diabetes tipe 2 di pelayanan kesehatan primer. Jurnal Sains Farmasi dan Klinis. 2019 May 29;6(1):54-62.

14. Samu AM, Amirthalingam PS, Mohammed OS. Assessment of patient medication adherence among the type 2 diabetes mellitus population with peripheral diabetic neuropathy in South India. Journal of Taibah University Medical Sciences. 2017 Apr;12(2):164-8.

15. Khotkar K, Chaudhari S, Jadhav PR, Deshmukh YA. Assessment of medication adherence in type II diabetic patients: a cross-sectional study. MGM Journal of Medical Sciences. 2017 Jun;4(2):65-9.

16. Wibowo A. Metodologi penelitian praktis bidang kesehatan. Jakarta: Rajawali Pers; 2014. p. 1-298.

17. Retnawati H. Analisis kuantitatif instrumen penelitian. Edisi 1. Yogyakarta: Parama Publishing; 2016.

18. Riwidikdo H. Statistik kesehatan belajar mudah tehnik analisis data dalam penelitian kesehatan. Yogyakarta: Mitra Cendikia Press; 2012. p. 152.

19. Alfian R, Maulan A, Putra P. Uji validitas dan reliabilitas kuesioner medication adherence report scale (Mars) terhadap pasien diabetes mellitus. Jurnal Ilmiah Ibnu Sina. 2017 Sept;2(2):176-83.

20. Toma G, Guetterman TC, Yaqub T, Talaat N, Fetters MD. A systematic approach for accurate translation of instruments: experience with translating 
the Connor-Davidson Resilience Scale into Arabic. Methodological Innovation. 2017 Dec 21;10(3).

21. Braekman E, Berete F, Charafeddine R, Demarest S, Drieskens S, Gisle L, et al. Measurement agreement of the selfadministered questionnaire of the Belgian Health Interview Survey: paper-andpencil versus web-based mode. PLoS ONE. 2018 May 21;13(5).

22. Rasdianah N, Martodiharjo S, Andayani TM, Hakim LN. The description of medication adherence for patients of diabetes mellitus type 2 in public health center Yogyakarta. Indonesian Journal of Clinical Pharmacy. 2016 Dec;5(4):24957.

23. Rosyida L, Priyandani Y, Sulistyarini A, Nita Y. Kepatuhan pasien pada penggunaan obat antidiabetes dengan metode pill-count dan MMAS-8 di Puskesmas Kedurus Surabaya. Jurnal Farmasi Komunitas. 2015;2(2):36-41.

24. Perkumpulan Endokrinologi Indonesia. Konsesus pengelolaan dan pencegahan diabetes melitus tipe 2 di Indonesia. Jakarta: PB PERKENI; 2019. p. 1-82.

25. Kurniawaty E, Yanita B. Faktor-faktor yang berhubungan dengan kejadian diabetes melitus tipe II. Medical Journal of Lampung University. 2016;5(2):27-31.

26. Susanti ML, Sulistyarini T. Dukungan keluarga meningkatkan kepatuhan diet pasien diabetes mellitus di ruang rawat inap RS. Baptis Kediri. Jurnal STIKES. 2013 Jul;6(1).

27. Pusat Data dan Informasi Kemenkes. Infodatin: Situasi lanjut usia (lansia) di Indonesia 2016. Jakarta: Pusat Data dan Informasi Kementerian Kesehatan; 2016. p. 12.

28. Gobet F. The future of expertise: The need for a multidisciplinary approach. Journal of Expertise. 2018 Sept;1(2):10713.

29. Budiman, Riyanto A. Kapita selekta kuisoner: pengetahuan dan sikap dalam penelitian kesehatan. Jakarta: Salemba Medika; 2014.

30. Mahler C, Hermann K, Horne R, Ludt S, Haefeli WE, Szecsenyi J, et al. Assessing reported adherence to pharmacological treatment recommendations. Translation and evaluation of the medication adherence report scale (MARS) in
Germany. Journal of Evaluation in Clinical Practice. 2010 Jun;16(3):574-9.

31. Hc N, Gali A, Muraraiah S. Assessment of factors influencing adherence to antidiabetic drugs among patients with type 2 diabetes mellitus at a tertiary care hospital in India. Pharmacology and Clinical Pharmacy Research. 2020;5(1):1-7.

32. Ali M, Alemu T, Sada O. Medication adherence and its associated factors among diabetic patients at zewditu memorial hospital, Addis Ababa, Ethiopia. BMC Research Notes. 2017;10(1):1-5.

33. Ahmad NS, Ramli A, Islahudin F, Paraidathathu T. Medication adherence in patients with type 2 diabetes mellitus treated at primary health clinics in Malaysia. Patient Prefer Adherence. 2013 Jun 17;7:525-30.

34. Horii T, Momo K, Yasu T, Kabeya Y, Atsuda K. Determination of factors affecting medication adherence in type 2 diabetes mellitus patients using a nationwide claim-based database in Japan. PLoS ONE. 2019 Oct 8;14(10):112.

35. Saepudin, Padmasari S, Hidayanti P, Ningsih ES. Kepatuhan penggunaan obat pada pasien hipertensi di Puskesmas. Jurnal Farmasi Indonesia. 2013 Jul;6(4):246-53.

36. Octapermatasari R, Faridah IN. Hubungan Antara kepatuhan terapi dengan luaran terapi pada pasien dm tipe 2 di tiga puskesmas Kota Yogyakarta [disertasi]. Yogyakarta: Universitas Ahmad Dahlan; 2019.

37. Alfian R. Korelasi antara kepatuhan minum obat dengan kadar gula darah pada pasien diabetes melitus rawat jalan di RSUD Moch. Ansari Saleh Banjarmasin. Jurnal Pharmascience. 2015;2(2):15-23.

38. Wibowo MINA, Setiawan D, Ikhwaniati ND, Sukma FA. Pengaruh Konseling dan alat bantu pengingat pengobatan terhadap kepatuhan minum obat dan outcome klinik pasien diabetes melitus dan hipertensi. Jurnal Ilmu Kefarmasian Indonesia. 2020 Okt;18(2):169-76.

39. Hapsari PN. Hubungan antara kepatuhan penggunaan obat dan keberhasilan terapi pada pasien diabetes mellitus instalasi rawat jalan di RS X Surakarta [skripsi]. 
Surakarta: Universitas Muhammadiyah Surakarta; 2014.

40. Al-Qazaz HKh, Sulaiman SA, Hassali MA, Shafie AA, Sundram S, Al-Nuri R, et al. Diabetes knowledge, medication adherence and glycemic control among patients with type 2 diabetes. International Journal of Clinical Pharmacy. 2011 Dec;33(6):1028-35.

41. Wong MCS, Wu CHM, Wang HHX, Li HW, Hui EMT, Lam AT, et al. Association between the 8-item morisky medication adherence scale (MMAS-8) score and glycaemic control among Chinese diabetes patients. Journal of Clinical Pharmacology. 2015 Mar;55(3):279-87.

42. Bazaev NA, Pletenev AN, Pozhar KV. Classification of factors affecting blood glucose concentration dynamics. Biomedical Engineering. 2013 Jul 18;47:100-3.

43. Shahin W, Kennedy GA, Stupans I. The impact of personal and cultural beliefs on medication adherence of patients with chronic illnesses: a systematic review. Patient Prefer Adherence. 2019 Jul 1;13:1019-35.

44. Yap AF, Thirumoorthy T, Kwan YH. Medication adherence in the elderly. Journal of Clinical Gerontology and Geriatrics. 2016 Jun;7(2):64-7.

45. Tashandra N. Menu Sarapan orang Indonesia didominasi karbohidrat [Internet]. Kompas Lifestyle; 2018 Apr 22 [disitasi 10 Juni 2020]. Available from:

https://lifestyle.kompas.com/read/2018/04 /22/131500520/menu-sarapan-orangindonesia-didominasikarbohidrat?page $=$ all

46. Farmer AJ, Rodgers L, Lonergan $\mathrm{M}$, Shields B, Weedon M, Donnelly L, et al. Adherence to oral glucose-lowering therapies and associations with 1-year Hbalc: a retrospective cohort analysis in a large primary care database. Diabetes Care. 2015 Dec 17;39(2).

47. Thom CS, Dickson CF, Gell DA, Weiss MJ. Hemoglobin variants: biochemical properties and clinical correlates. Cold Spring Harbor Perspective in Medicine. 2013 Mar 1;3(3).

48. Furusyo N, Hayashi J. Glycated albumin and diabetes mellitus. Biochimica et
Biophysica Acta.

Dec;1830(12):5509-14.

2013

49. Doggrell SA, Warot S. The association between the measurement of adherence to anti-diabetes medicine and the $\mathrm{HbAlc}$. International Journal of Clinical Pharmacy. 2014 Jun;36(3):488-97.

50. Al-Qazaz HK, Sulaiman SA, Hassali MA, Shafie AA, Sundram S, Al-Nuri R, et al. Diabetes knowledge, medication adherence and glycemic control among patients with type 2 diabetes. International Journal of Clinical Pharmacy. 2011;33(6):1028-35.

51. Sankar U V, Lipska K, Mini GK, Sarma PS, Thankappan KR. The adherence to medications in diabetic patients in rural Kerala, India. Asia-Pacific Journal of Public Health. 2015;27(2):NP513-23.

52. Garfield S, Clifford S, Eliasson L, Barber N, Willson A. Suitability of measures of self-reported medication adherence for routine clinical use: A systematic review. BMC Medical Research Methodology. 2011;11:149.

53. Bender BG. Advancing the science of adherence measurement: implications for the clinician. The Journal of Allergy and Clinical Immunology: In Practice. 2013 Jan 1;1(1):92-3.

54. Nguyen TMU, Caze A La, Cottrell N. What are validated self-report adherence scales really measuring?: a systematic review. British Journal of Clinical Pharmacology. 2014 mar;77(3):427-45.

55. Stirratt MJ, Dunbar-Jacob J, Crane HM, Simoni JM, Czajkowski S, Hilliard ME, et al. Self-report measures of medication adherence behavior: recommendations on optimal use. Translational Behavioral Medicine. 2015 Dec;5(4):470-82. 